\title{
Phenobarbital Measurement
}

National Cancer Institute

\section{Source}

National Cancer Institute. Phenobarbital Measurement. NCI Thesaurus. Code C75368.

The determination of the amount of phenobarbital present in a sample. 